\title{
Effect of starch type and screw speed on mechanical properties of extrusion-cooked starch-based foams
}

\author{
Maciej Combrzyński ${ }^{1}{ }^{\circledR}$, Agnieszka Wójtowicz ${ }^{1}{ }^{\circledR}$, Marcin Mitrus ${ }^{1}{ }^{\circledR}$, Tomasz Oniszczuk $^{1}$, \\ Arkadiusz Matwijczuk ${ }^{2}$, Paulina Pawelczyk ${ }^{1}$, and Leszek Mościcki ${ }^{1}$ (]) \\ ${ }^{1}$ Department of Thermal Technology and Food Process Engineering, University of Life Sciences in Lublin, Głęboka 31, \\ 20-612 Lublin, Poland \\ ${ }^{2}$ Department of Physics, University of Life Sciences in Lublin, Akademicka 13, 20-950 Lublin, Poland
}

Received September 16, 2018; accepted December 18, 2018

\begin{abstract}
Potato starch and corn starch are popular basic raw materials in the processing of biopolymers. One of the processing methods employed in the manufacture of biopolymers is extrusion-cooking technique. With specific parameters and equipment configurations, it is possible to obtain a wide variety of starch-based biopolymers. Loose fill foams are usually produced with the use of polystyrene, but the adverse environmental effects of conventional plastics provide an incentive for the development of new, environmentally friendly raw materials. The aim of the study was to apply the extrusion-cooking technique to prepare starch-based foams from potato starch and corn starch under various extruder screw speeds applied during processing. Process efficiency and energy consumption were also tested during processing. The expanded foams were analysed by means of cutting and compression tests to evaluate selected mechanical properties. The type of starch used and the processing screw speed had an impact on the efficiency and specific energy requirements of the process. The results showed that the screw speed had a significant effect on the cutting forces in the tested foams as well as on its compression properties. Higher hardness of foams was observed when potato starch was used as the basic raw material. Moreover, corn starch foams proved to be more elastic in compression tests.

Keywords: corn starch, potato starch, foams, compression test, elastic modulus
\end{abstract}

\section{INTRODUCTION}

Recent years have seen a growing application of plastics in all areas of human activity. At present, it is difficult to imagine life without plastics: packaging, toys, cars, medical products, etc. have become part of everyday reality. However, besides their unquestionable benefits, they may

*Corresponding author e-mail: maciej.combrzynski@up.lublin.pl agnieszka.wojtowicz@up.lublin.pl also pose a threat due to their ubiquity. The problem of packaging waste management is ranked among the major challenges of 21 st-century society. In recent decades, the global population has grown rapidly; and global consumption has also increased to an even greater extent, which, stimulated by a variety of marketing tools, is contributing to the manufacture of an unprecedented volume of packaged products. The end of the 20th century is considered to have brought significant changes to the development of the packaging industry (Combrzyński et al., 2018a). The environmental awareness of consumers, which has been growing for many years, and the fashion for "green products" has fostered the design of plastics, which undergo rapid decomposition (biodegradation) after their life cycle expires.

One of the groups of biodegradable materials has a natural origin and is produced from various types of starch (Combrzyński et al., 2018b; Chocyk et al., 2015; Oniszczuk et al., 2013). Starch has many possible applications, for example, in the food, paper, textile, and pharmaceutical industries. Griffin (1994) was the first to use starch as a filler in plastics. At present, polyethylene films with an addition of starch and other products based on this polysaccharide are widely available on the market. The technologies, which use native starch as an additive, maintain its quantity below $10 \%$ of final product weight. However, at the present time, researchers are striving to produce a purely starchy material that is suitable for the production of disposable commercial items, such as plates, forks, cups, and garden items, e.g.

(C) 2019 Institute of Agrophysics, Polish Academy of Sciences 
pots or foil (Gładyszewska et al., 2013; Muszyński et al., 2017; Rejak et al., 2013; Oniszczuk and Pilawka, 2013). One of the applications of starch could be the production of foams as protective materials instead of traditional polystyrene foams. There are some reports about the application of starch foam products for use in cushioning and insulation applications (Nabar et al., 2006; Pushpadass et al., 2008; Willett and Shogren, 2002; Zhang and Sun, 2007).

In order to undergo further processing as a biodegradable material, unprocessed starch must be transformed into thermoplastic starch (TPS). Biopolymers are obtained after mixing starch with a plasticizer (often glycerol or water) to allow for the melting of the material at a temperature lower than the decomposition temperature of starch, e.g. during the extrusion-cooking process (Mościcki et al., 2007). The main advantages of starch are: biodegradability, broad availability, relatively low cost and straightforward chemical modification (Teixeira et al., 2007; Mościcki et al., 2012). The properties of TPS depend on the natural origin of the starch, more specifically, on the ratio of its main two components: linear amylose and branched amylopectin. Numerous studies have been published concerning the effect of amylose and amylopectin content on the final properties of starch-based materials (Zou et al., 2012). TPS obtained from high-amylose starch has been proven to have better thermal and mechanical properties; however, its processing requirements (extrusion, in particular) are much more demanding (Stasiak et al., 2013). Unfortunately, pure thermoplastic starch has several disadvantages. These are: low mechanical strength (fragility) and high sensitivity to environmental factors, e.g. moisture (Carvalho et al., 2003; Muszyński et al., 2016).

In order to improve the physical properties of starch biopolymers, and possibly even reduce the price of the finished product, various types of fillers are added to the materials. Fillers have an impact on the mechanical, technological, physical and chemical properties of the final product (Oniszczuk et al., 2015; Stasiak et al., 2017). Depending on their origin, fillers may be organic or inorganic, and supplied in the powdered, fibrous, or lamellate forms. Emulsifiers, cellulose, plant fibre, bark, kaolin, pectin, or wood waste may all be used as fillers (SzyszlakBarglowicz et al., 2013). They have a major impact on the technological properties of polymers (Ayse and Mohini, 2008; Zhang et al., 2005).

Starch biopolymers are obtained using the same machinery as synthetic polymers but also with food extruders, which is a novel approach (Mitrus and Mościcki, 2014). Traditional extruders used in the manufacture of plastics are not suitable for processing starch material in a manner that is reasonably likely to produce the intended quality characteristics. Food extruders have a specific plasticizing system, i.e. a cylinder grooving arrangement, and a variable screw configuration.
During extrusion-cooking at high temperature, pressure and shear forces, a process of the gelatinization of starch occurs, which alters its physical and chemical characteristics. The extrusion-cooking conditions can have an impact on the final properties of the product. Variable configuration of single or twin-screw extruders, screw profiles, the heating or cooling of different sections of the extruder and the use of dies with various shapes allow to produce a variety of products (Combrzyński et al., 2018a). The involvement of scientific and industrial developers in furthering green technologies has the potential to establish an appropriate balance between economic interest and environment protection. Natural materials, previously considered too expensive and unprofitable, will most likely be the only realistic possibility to maintain optimum social development without the gradual degradation of the environment.

The aim of the study was to apply the extrusion-cooking technique to produce starch-based foams with various types of starch and processing conditions applied. The starch foams were made using potato starch and corn starch at various extruder-cooker screw speeds applied during processing.

\section{MATERIALS AND METHODS}

Two types of starch were used in the study as raw materials: potato starch (Superior Standard, PPZ Trzemeszno, Poland) and native corn starch $\left(\mathrm{C}^{*} \mathrm{Gel} 03401\right.$ type, Cargill Poland Sp. zo.o., Poland). The moisture content was $16.7 \%$ and the $\mathrm{pH}$ was 7.4 and $15.2 \%$ and $\mathrm{pH} 7.2$ for potato starch and for corn starch, respectively. The starch was moistened with water till it reached a value of $18 \%$ moisture content (the starch was then set aside for $24 \mathrm{~h}$ ) and mixed before processing.

The processing of the starch foams was performed using the TS-45 single screw extruder-cooker (Gliwice, Poland) with an $\mathrm{L} / \mathrm{D}$ ratio of 12 . The foams were processed in a temperature range between $80-120^{\circ} \mathrm{C}$ with various screw speeds (70, 100 and $130 \mathrm{rpm})$ using a circular forming die ( $3 \mathrm{~mm}$ in diameter), the length of the samples were $25 \mathrm{~mm}$.

The process efficiency $\left(\mathrm{kg} \mathrm{h}^{-1}\right)$ was evaluated as the mass of a sample collected at a specific time in 3 repetitions, and specific mechanical energy (SME, $\mathrm{kWh} \mathrm{kg}^{-1}$ ) was calculated for each run as described by Kręcisz et al. (2015).

Selected mechanical properties of the foams obtained were evaluated. The cutting force and resistance to compression were measured using the Zwick/Roell BDOFBO0.5TH universal testing machine (Ulm, Germany). In order to perform the cutting test, Warner-Bratzler's equipment was used (Jin et al., 1995; Mitrus and Moscicki, 2014). The samples were placed at an angle of $90^{\circ}$ to the cutting knife and tested at a working head speed of 100 $\mathrm{mm} \mathrm{min}^{-1}$. The initial force was set at $0.1 \mathrm{~N}$ before the results were recorded. Force-displacement curves were 
used to analyse the results with testXpertIIv3.3 software. Selected characteristics of the foams were evaluated, such as the maximum cutting force $(\mathrm{N})$, strain at the maximum cutting force (\%), the cutting force at the breaking point $(\mathrm{N})$ and strain at the cutting force at the breaking point (\%). The strain at the maximum cutting force was registered as the displacement recorded at maximum cutting force with respect to the diameter of the tested sample. The strain at the cutting force at the breaking point was recorded as the displacement at the breaking point of the sample with respect to its diameter. These results were obtained at the defined dimension of each sample.

A compression test was performed with two flat plates to evaluate the elastic modulus $(\mathrm{kPa})$, the maximum compression force $(\mathrm{N})$, strain at the maximum compression force $(\%)$, and work at the maximum compression force $(\mathrm{J})$. Strain at the maximum compression force was registered as the displacement recorded at maximum compression force with respect to the diameter of the tested sample. Work at the maximum compression force was defined on the basis of the area under the compression curve until maximum force was reached. The testXpertIIv3.3 software was used for the analysis of the results. The compression test was carried out at up to $50 \%$ of the original sample height with a test speed of $100 \mathrm{~mm} \mathrm{~min}^{-1}$ and with an initial force of $0.1 \mathrm{~N}$ before the results were recorded (Filli et al., 2011; Mitrus and Moscicki, 2014; İbanoğlu et al., 2006). The relevant measurements were made in the transverse direction to the diameter of extrudates produced All of the mechanical properties were replicated 10 times for each sample.

The results obtained during these multiple tests were analysed using Statistica 13.3 (StatSoft, Poland). Linear equations were adapted to the data. For the analysis of the effect of starch type and screw speed, the F-test was applied at a level of $\alpha=0.05$.

\section{RESULTS AND DISCUSSION}

The significant effects on process efficiency of the different screw speeds applied during the processing of starch foams were reported for both potato and corn starch (Table 1). The foams extruded from potato starch revealed a higher efficiency than the corn starch foams (Fig. 1a). In both cases, a significant increase in efficiency was observed with increasing screw speed applied during processing. The efficiency reported for potato starch foam varied from 13.6 to $27.4 \mathrm{~kg} \mathrm{~h}^{-1}$ with almost $200 \%$ higher efficiency achieved when the highest screw speed $(130 \mathrm{rpm}$. v.s. the lowest speed of $70 \mathrm{rpm}$ ) was applied. For corn starch foam, the results were much lower and ranged from 10.2 to $14.8 \mathrm{~kg} \mathrm{~h}^{-1}$, thus, the increase in efficiency was only $48 \%$ when the highest screw speed was used.

As regards energy requirements, SME was lower when potato starch was processed (Fig. 1b). Higher energy requirements were observed during the processing of corn
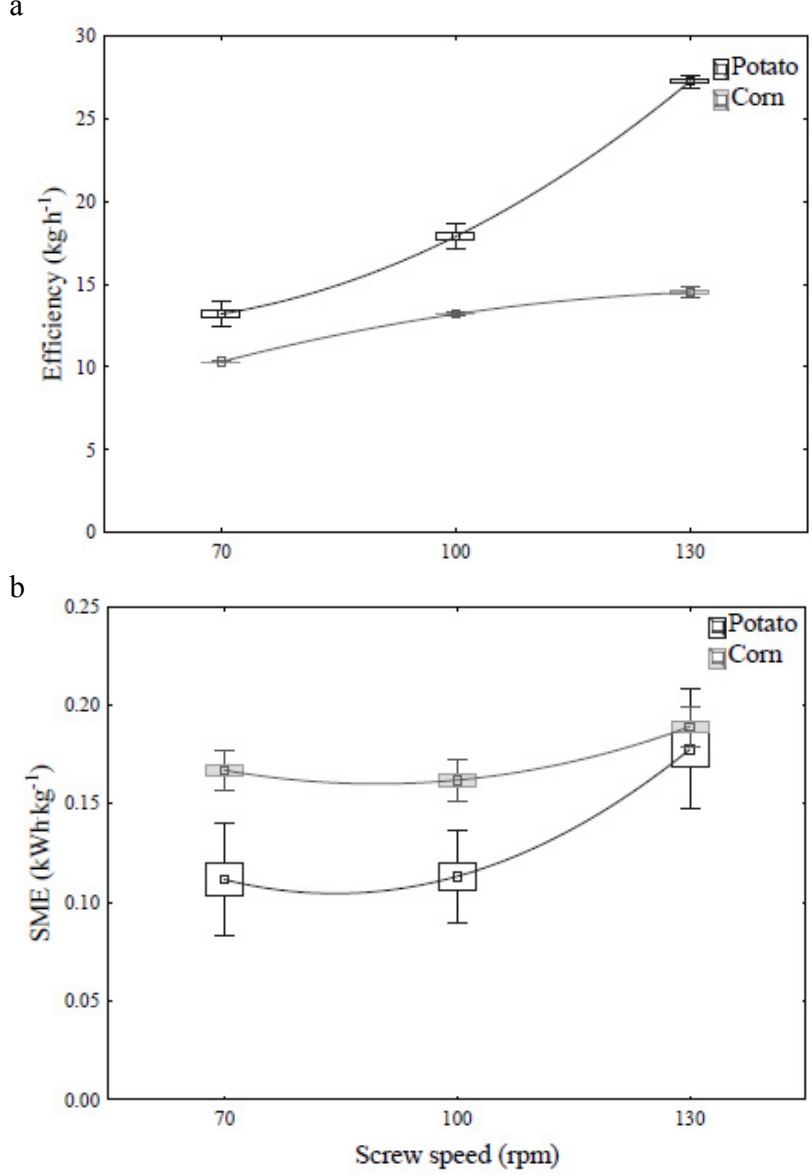

Fig. 1. Processing efficiency (a) and energy consumption (b) during processing of potato and corn starch foams under various screw speeds.

starch, especially at a low screw speed. The application of $130 \mathrm{rpm}$ for the extrusion-cooking of foams showed similar specific mechanical energy requirements but with a much higher process efficiency being observed for potato starch. This may be attributed to the effect of the lower gelatinization temperature of potato starch compared with corn starch and, thus, the lower viscosity of melted starch inside the extruder-cooker barrel. Therefore, a less dense mass can be pushed through the barrel sections and forced through the die more easily, which means that a higher level of efficiency and lower energy consumption is observed for potato starch. The SME values increased along with the rising screw speed during processing. The F-test confirmed that the effect of the screw speed was significant for both potato and corn starch (Table 1).

Cutting tests allow for the evaluation of the hardnessof tested samples. The cutting force values required to break the structure of the tested foams are presented in Fig. 2a. A much lower force at the breaking point (four times lower on average) was measured for corn starch foams than for potato starch foams. A significant decrease in the cutting force at the breaking point from 196.2 to $149.3 \mathrm{~N}$ was observed when the screw speed was increased during 
Table 1. Statistical analysis of the effect of screw speed on selected properties of starch foams

\begin{tabular}{|c|c|c|c|c|c|}
\hline Characteristic & Starch type & Equation & $r$ & F-test & $\mathrm{p}$ \\
\hline \multirow{2}{*}{$\begin{array}{l}\text { Efficiency } \\
\left(\mathrm{kg} \cdot \mathrm{h}^{-1}\right)\end{array}$} & Potato & $-3.96+0.234 x$ & 0.981 & 1277.64 & 0.0000 \\
\hline & Corn & $5.684+0.0698 x$ & 0.976 & 1187.53 & 0.0000 \\
\hline \multirow{2}{*}{$\begin{array}{l}\text { SME } \\
\left(\mathrm{kWh}^{-1} \mathrm{~kg}^{-1}\right)\end{array}$} & Potato & $0.024+0.001 x$ & 0.822 & 22.13 & 0.0017 \\
\hline & Corn & $0.136+0.0004 x$ & 0.721 & 23.83 & 0.0014 \\
\hline \multirow{2}{*}{$\begin{array}{l}\text { Maximum cutting force } \\
(\mathrm{N})\end{array}$} & Potato & $292.712-1.248 x$ & -0.962 & 83.06 & 0.00004 \\
\hline & Corn & $124.367-0.295 x$ & -0.790 & 6.87 & 0.0281 \\
\hline \multirow{2}{*}{$\begin{array}{l}\text { Strain at max. cutting } \\
\text { force }(\%)\end{array}$} & Potato & $88.900-0.428 x$ & -0.951 & 66.74 & 0.00008 \\
\hline & Corn & $21.087-0.107 x$ & -0.824 & 7.97 & 0.0204 \\
\hline \multirow{2}{*}{$\begin{array}{l}\text { Cutting force at the } \\
\text { breaking point }(N)\end{array}$} & Potato & $249.795-0.806 x$ & -0.918 & 18.34 & 0.0028 \\
\hline & Corn & $67.242-0.287 x$ & -0.725 & 3.38 & 0.1039 \\
\hline \multirow{2}{*}{$\begin{array}{l}\text { Strain at cutting force at } \\
\text { the breaking point }(\%)\end{array}$} & Potato & $82.838-0.321 x$ & -0.989 & 147.45 & 0.00001 \\
\hline & Corn & $24.644-0.121 x$ & -0.882 & 10.63 & 0.0107 \\
\hline \multirow{2}{*}{$\begin{array}{l}\text { Maximum compression } \\
\text { force }(\mathrm{N})\end{array}$} & Potato & $369.998-1.742 x$ & -0.984 & 127.75 & 0.00001 \\
\hline & Corn & $167.782-0.643 x$ & -0.919 & 19.15 & 0.0025 \\
\hline \multirow{2}{*}{$\begin{array}{l}\text { Strain at max. } \\
\text { compression force }(\%)\end{array}$} & Potato & $60.933-0.213 x$ & -0.928 & 19.07 & 0.0025 \\
\hline & Corn & $43.0411-0.247 x$ & -0.921 & 19.33 & 0.0024 \\
\hline \multirow{2}{*}{ Elastic modulus $(\mathrm{kPa})$} & Potato & $7539.067-37.937 x$ & -0.969 & 1626.72 & 0.0000 \\
\hline & Corn & $2310.311-15.689 x$ & -0.939 & 116.39 & 0.00002 \\
\hline \multirow{2}{*}{$\begin{array}{l}\text { Work at max. } \\
\text { compression force }(\mathrm{J})\end{array}$} & Potato & $0.7389-0.0031 x$ & -0.888 & 34.40 & 0.0005 \\
\hline & Corn & $0.1967-0.0005 x$ & -0.596 & 1.75 & 0.2519 \\
\hline
\end{tabular}

the processing of potato starch foams. Much lower cutting forces at the breaking point were noted when corn starch foam was tested (from $49.1 \mathrm{~N}$ at $70 \mathrm{rpm}$ up to 31.2 $\mathrm{N}$ at $130 \mathrm{rpm}$ ) and for these samples the significant effect of the screw speed was also observed (Table 1). Similar trends were observed in the results for the maximum cutting force (Fig. 2b), but the differences between the starch types were lower. The maximum cutting force ranged from 104.8 to $80.6 \mathrm{~N}$ for corn starch foams processed at 70 and $130 \mathrm{rpm}$, respectively. Higher results, ranging from 206.4 to $126.5 \mathrm{~N}$, were noted for potato foams processed at 70 and 130 screw speeds, respectively. The results of the cutting tests were evaluated at the defined diameter of each sample. Corn starch foams were less brittle and easier to break than the potato-based samples. Potato starch has a lower gelatinization temperature than corn starch (Mitrus and Moscicki, 2014). For corn starch foams higher diameter foams were observed with smaller air cells and thinner cell walls as compared to potato foams and this was the effect of a more intensive expansion of the corn starch when processed with extrusion-cooking due to the mechanical shearing and thermal treatment of the starch. This could be connected with the lower glass transition temperature of potato starch and thus the more intensive changes, which occurred inside the extruder barrel, resulting in gelatinized starch entering an amorphous state and 

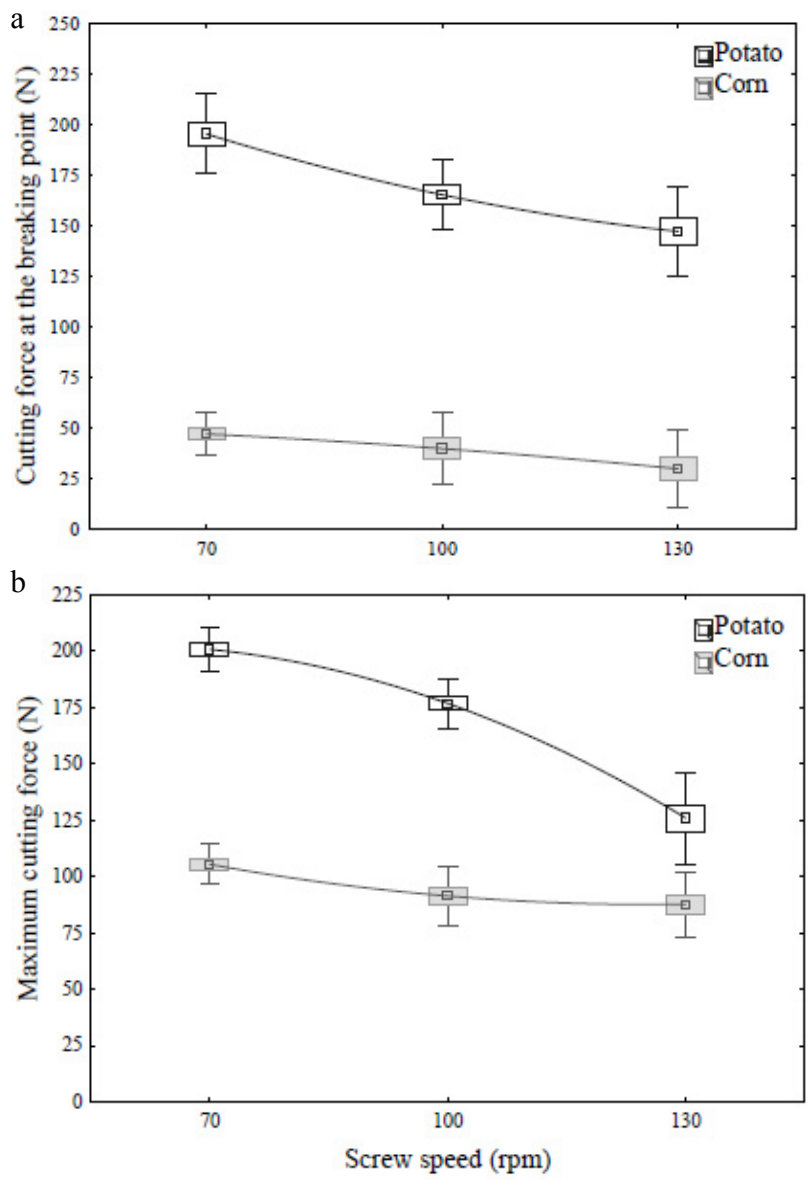

Fig. 2. Cutting force at the breaking point (a) and maximum cutting force (b) of potato and corn starch foams processed at various screw speeds.

also the lower expansion capacity due to the formation of less porous extrudates (Mercier et al., 1989; Thomas and Atwell, 1999). Della Valle et al. (1995) reported that potato starch processed using a twin-screw extruder-cooker showed higher values of viscosity compared with other starches processed under the same extrusion-cooking conditions, which were attributed to higher molecular weights of amylose and amylopectin. Moreover, they found potato starch in a molten state in sections in which other starch origins are usually conveyed under a solid form. In both kinds of tested foams, a decrease in hardness was observed along with increasing screw speed during processing. This may be attributed to a more porous internal structure and greater expansion when the material is extruded at a higher screw speed (Wójtowicz et al., 2015).

The cutting test causes the intense deformation of samples until they break. The strain is expressed as a \% of the difference between the sample height and dimensions at the cutting force at the breaking point as well as at the maximum cutting force. The results are presented in Fig. 3a and $3 b$. In both cases, a decrease in foam elasticity was observed along with the increasing screw speed applied during processing. The effect of the screw speed was significant for

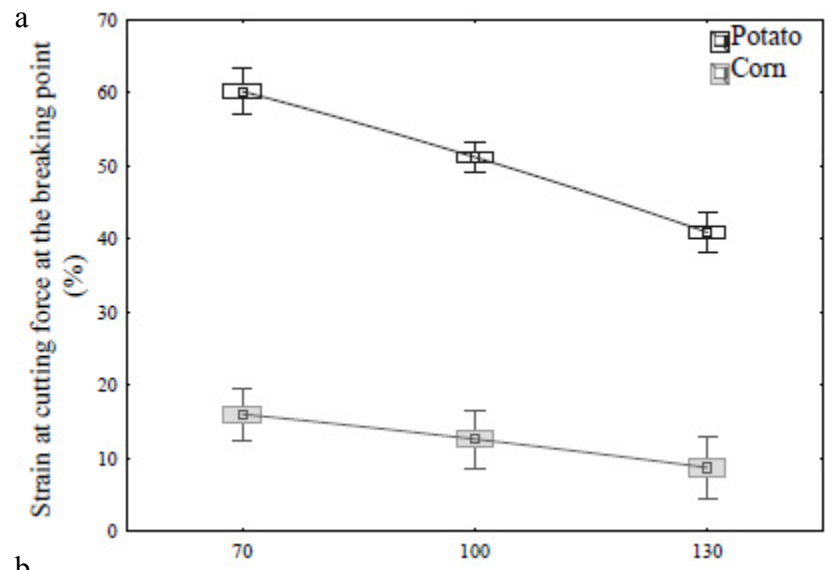

$\mathrm{b}$

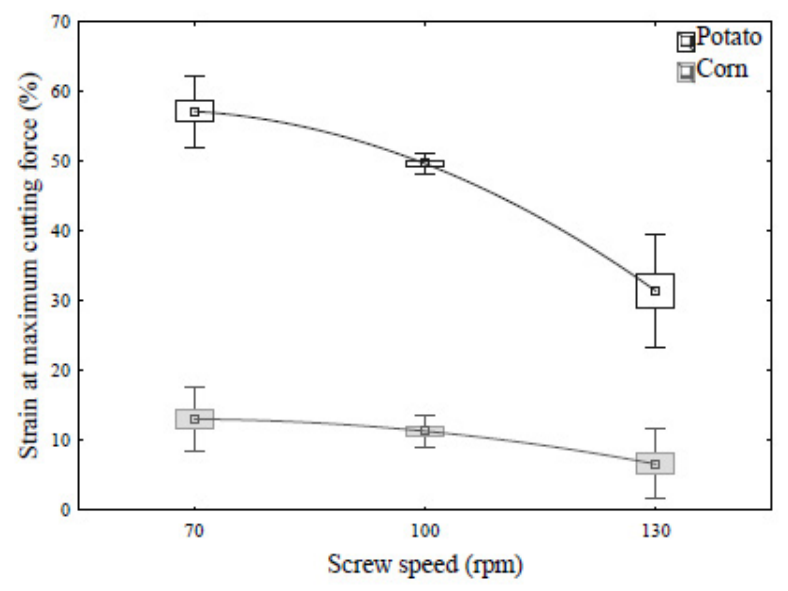

Fig. 3. Results of strain at cutting force at the breaking point (a) and at maximum cutting force (b) of potato and corn starch foams processed at various screw speeds.

potato starch (Table 1). Important parameters that affect the final dimension and qualities of the extrudate are die geometry, material properties, and processing parameters (especially screw speed) (Wang et al. 2005). Agbisit et al. (2007) reported that an increase in extruder-cooker screw speed would lead to a higher level of mechanical energy input, and therefore increased expansion. Similar observations have been made in the presented study. For corn starch foams a higher diameter was observed compared to the potato starch foams formed due to higher SME during processing.

For potato starch foams the results showed a similar strain during cutting which ranged from 61.8 to $42.3 \%$ and from 57.6 to $34.2 \%$ depending on the increasing screw speed measured at the breaking point and at the maximum force applied, respectively. The strain was reduced as the screw speed increased. A much lower strain, which ranged from 17.2 to $9.1 \%$ and 13.1 to $8.2 \%$, was observed for corn foams, and the differences between the samples were less significant due to the higher screw speed. A higher strain was noted for potato foams, which were characterized by a higher cutting force due to a denser internal structure and fewer air bubbles. In summary, under the cutting test the 


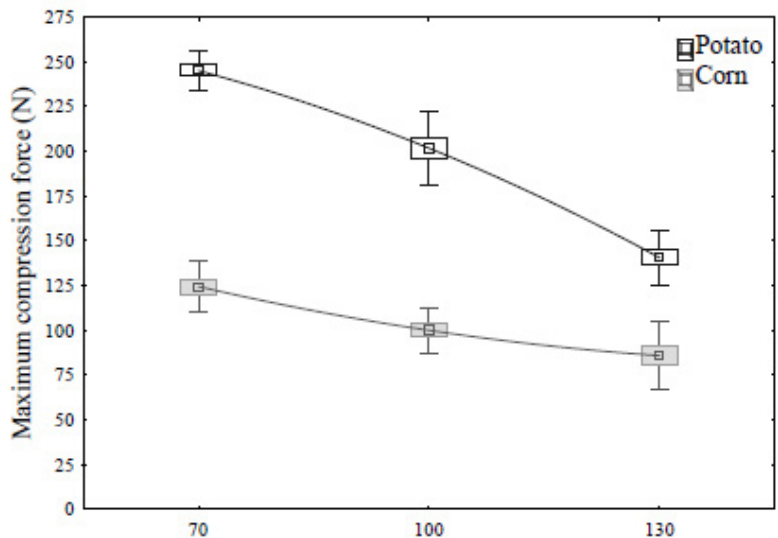

b

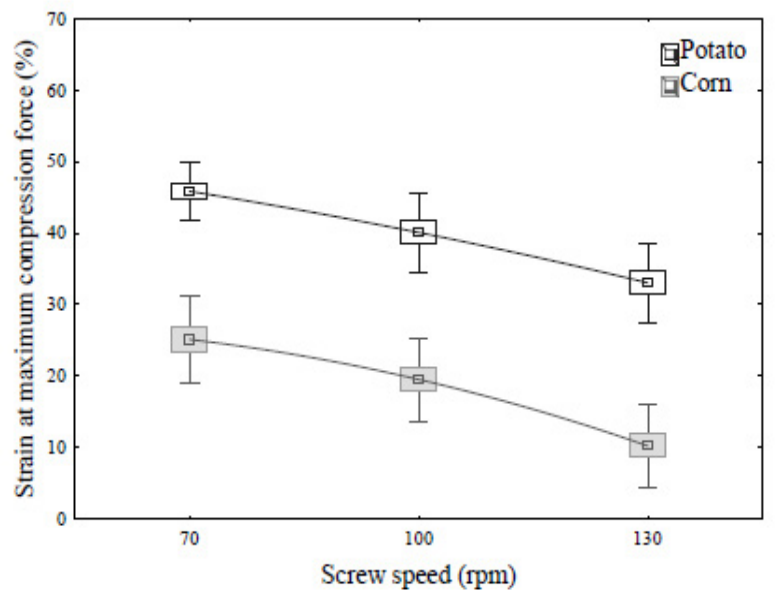

Fig. 4. Results of maximum compression force (a) and strain at maximum compression force (b) of potato and corn starch foams processed at various screw speeds.

structure of corn foams were less elastic and samples broke very easily because of the large size of the empty cells inside the foams. Therefore, a lower strain was recorded.

Similar trends were observed when a compression test was used to evaluate some selected mechanical properties of potato and corn extruded foams. Figure 4 show the effects of the screw speed and starch type on the maximum compression force and strain at the maximum compression force. The mean maximum compression force values, which ranged from 244.6 to $141.2 \mathrm{~N}$ for the potato foam, were twice as high as the values observed for the corn foam. For corn-based foamed materials, the mean values of the maximum compression force ranged from 126.1 to $81.4 \mathrm{~N}$. A statistical analysis demonstrated the significant effect of the screw speed on the maximum compression force for both potato and corn starch foams (Table 1). A lower resistance to compression was more visible $(43.1 \%)$ in potato starch foams than in corn starch foams $(29.6 \%)$ with the increase in screw speed being applied during the foam processing. A higher level of efficiency at higher screw speeds resulted in a more expanded structure (Combrzyński et al., 2018a), although samples were less resistant to compres- sion. Foam strain during the compression test was lower than that observed in the cutting test for potato foams; however, it was higher than for corn starch. Mean values ranging from 45.9 to $33.8 \%$ were obtained and higher results were noted for potato foams compare to the corn starch foams. For corn materials, the strain at maximum compression force ranged from 25.6 to $11.3 \%$. This lower strain result may be the result of the more compact structure of corn foams, demonstrated a lower porosity, which raises the strain under constant compression as opposed to breaking during the cutting test. The strain values in samples made from potato starch were twice as high as the ones observed for corn starch foams (Fig. 4b). The strain at compression decreased significantly with increasing screw speed during processing (Table 1). The results of the compression test obtained confirmed the differences between the extrusioncooking of potato and corn starch foams (Agbisit et al., 2007; Della Valle et al., 1995; Mercier et al., 1989; Thomas and Atwell, 1999; Wang et al., 2005).

The values of the elastic modulus, as shown in Fig. 5a, decreased significantly when a higher screw speed was applied during the processing of starch corn foams. A major difference was reported between the starch types. The
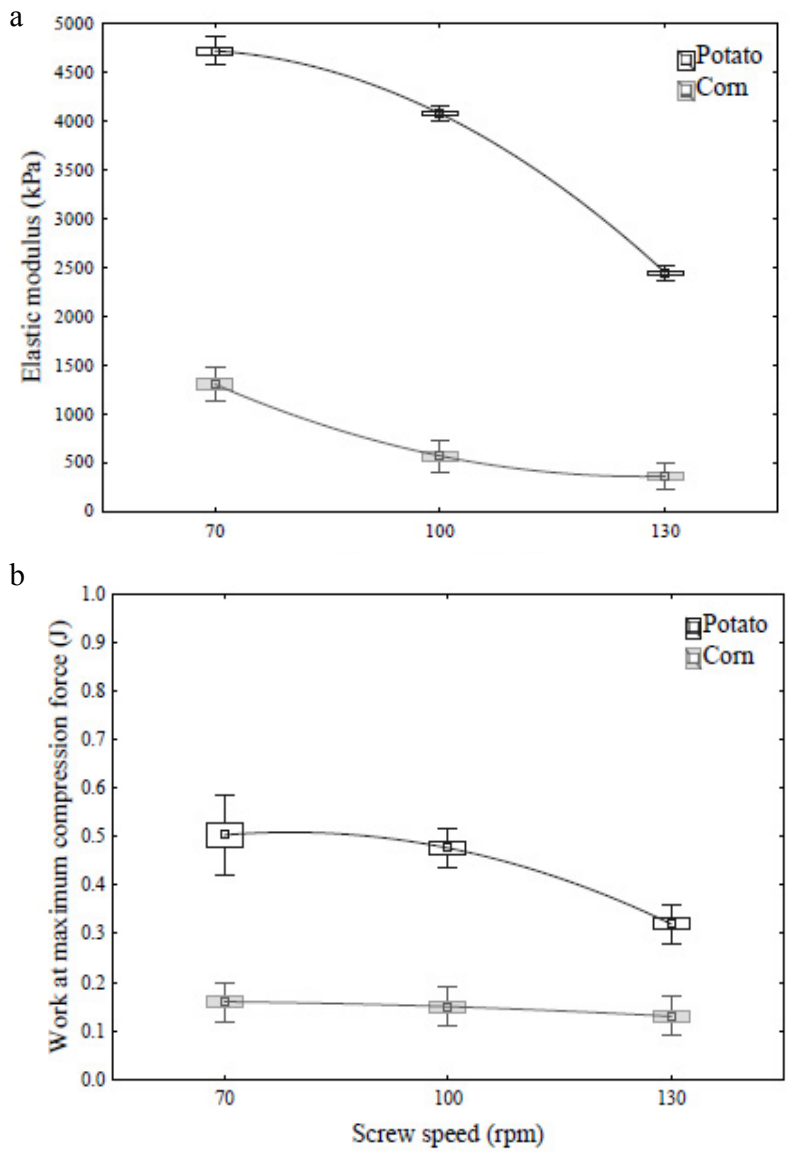

Fig. 5. Elastic modulus (a) and work at maximum compression force (b) of potato and corn starch foams processed at various screw speeds. 
elastic modulus evaluated during the compression test of potato foams ranged from 4789 to $2455 \mathrm{kPa}$, and a rapid decrease was observed with increasing screw speed applied during processing. A significantly lower elastic modulus was observed when corn foams were compressed. It varied from 1280 to $485 \mathrm{kPa}$ if 70 and $130 \mathrm{rpm}$ were used for extrusion-cooking, respectively. A higher elastic modulus was noted for potato foams, similar to the strain results registered under the cutting test because the potato foams were characterized by a denser structure and a lower degree of expansion as compared to the corn foams. The elastic modulus of the corn foams was lower, similar to the results of the strain, due to the tendency towards easier breaking under compression.

The negligible effect of the screw speed was noted when measuring the work values at the maximum compression force of starch corn foams (Table 1). The work values were very low, around $0.16-0.13 \mathrm{~J}$, for corn starch foams and from 0.55 to $0.32 \mathrm{~J}$ for potato starch foams. This may be attributed to the low elasticity of starch foams as compared to polymer foams as they yield to breaking instead of elastic compression. It could also be connected with the action of moisture contained in the air on starchy biopolymers, which may affect product elasticity and resistance to compression (Mitrus, 2012).

\section{CONCLUSIONS}

1. Starch foams processed by the extrusion-cooking technique exhibit various mechanical properties depending on screw speed and starch type.

2. The processing efficiency and specific mechanical energy increased at higher screw speeds during foam extrusion-cooking. A higher level of efficiency and lower energy requirements were reported when potato starch was used.

3. Higher values of mechanical properties were observed when potato starch foams were tested, both in cutting and compression tests.

4. The best properties with regard to high efficiency level, low energy consumption and high resistance to breaking were found if potato starch was used for the processing of foams at a screw speed of $100 \mathrm{rpm}$.

Conflict of interest: The Authors do not declare conflict of interest.

\section{REFERENCES}

Agbisit R., Alavi S., Cheng E., Herald T., and Trater A. 2007. Relationships between microstructure and mechanical properties of cellular cornstarch extrudates. J. Texture Studies, $38,199-219$. https://doi.org/10.1111/j.1745-4603.2007.00094.x

Ayse A. and Mohini S., 2008. Biocomposites from wheat straw nanofibers: morphology, thermal and mechanical properties. Composites Sci. Technol., 68, 557-565. https://doi.org/10.1016/j.compscitech.2007.05.044
Carvalho A.J.F., Job A.E., Alves N., Curvelo A.A.S., and Gandini A., 2003. Thermoplastic starch/natural rubber blends. Carbohydrate Polymers, 53, 95-99. https://doi.org/10.1016/s0144-8617(03)00005-5

Chocyk D., Gladyszewska B., Ciupak A., Oniszczuk T., Mościcki L., and Rejak A., 2015. Influence of water addition on mechanical properties of thermoplastic starch foils. International Agrophysics, 29(3), 267-275. https://doi.org/10.1515/intag-2015-0031

Combrzyński M., Mościcki L., Kwaśniewska A., Oniszczuk T., Wójtowicz A., Kręcisz M., Sołowiej B., Gladyszewska B., and Muszyński S., 2018a. Effect of PVA and PDE on selected structural characteristics of extrusion-cooked starch foams. Polimeros-Ciencia e Tecnologia, 28(1), 76-83. https://doi.org/10.1590/0104-1428.02617

Combrzyński M., Matysiak A., Wójtowicz A, Oniszczuk T., Kupryaniuk K., Żelizko K., Kuboń M., Mazurkiewicz J., and Mitrus M., 2018b. Effect of foaming agent addition on starch foam properties (in Polish). Przemysł Chemiczny, 97(5), 682-685.

Combrzyński M., Mościcki L., Kwaśniewska A., Oniszczuk T., Wójtowicz A., Sołowiej B., Gladyszewska B., and Muszyński S., 2017. Moisture sorption characteristics of extrusion-cooked starch protective loose-fill cushioning foams. Int. Agrophys., 31(4), 457-463.

https://doi.org/10.1515/intag-2016-0071

Della Valle G., Boché Y., Colonna P., Vergnes B., 1995. The extrusion behaviour of potato starch, Carbohydrate Polymers, 28(3), 255-264.

https://doi.org/10.1016/0144-8617(95)00111-5

Filli K., Sjöqvist M., Öhgren C., Stading M., and Rigdahl M., 2011. Development and characterization of extruded biodegradable foams based on zein and pearl millet flour. Annual Transactions Nordic Rheology Society, 19, 139-145. https://doi.org/10.1080/10942910600596605

Gladyszewska B., Oniszczuk T., Ciupak A., Chocyk D., Mościcki L., Rejak A., and Gladyszewski G., 2013. Effect of sweet water on some mechanical properties of biodegradable thermoplastic starch films (in Polish). Przemysł Chemiczny, 92(8), 1525-1527. https://doi.org/10.1515/intag-2015-0031

Griffin G.J.L., 1994. Starch polymer blends. Polymer Degradation and Stability, 45(2), 241-247. https://doi.org/10.1016/0141-3910(94)90141-4

İbanoğlu Ş., Ainsworth P., Özer E.A., and Plunkett A., 2006. Physical and sensory evaluation of a nutritionally balanced gluten-free extruded snack. J. Food Eng., 75, 469-472. https://doi.org/10.1016/j.jfoodeng.2005.04.060

Jin Z., Hsiehl F., Huff H.E., 1995. Effects of soy fiber, salt, sugar and screw speed on physical properties and microstructure of corn meal extrudate. J. Cereal Sci., 22, 185-194. https://doi.org/10.1016/0733-5210(95)90049-7

Kręcisz M., Wójtowicz A., and Oniszczuk A., 2015. Effect of selected parameters on process efficiency and energy consumption during the extrusion-cooking of corn-rice instant grits. Agric. Agric. Sci. Procedia, 7, 139-145. https://doi.org/10.1016/j.aaspro.2015.12.008

Mercier C., Linko P., Harper J.M., 1989. Extrusion cooking. American Association of Cereal Chemists, St. Paul, Minnesota, USA. 
Mitrus M., 2012. Starch protective loose-fill foams. In: Thermoplastic Elastomers (Ed. A. El-Sonbati). InTech, Rijeka, Croatia, 79-94. https://doi.org/10.5772/36270

Mitrus M. and Moscicki L., 2014. Extrusion-cooking of starch protective loose-fill foams. Chemical Eng. Res. Design, 92, 778-783. https://doi.org/10.1016/j.cherd.2013.10.027

Mościcki L., Janssen L.P.B.M., Mitrus M., Oniszczuk T., Rejak A., and Juśko S., 2007. Baro-thermal techniques in processing of thermoplastic starch, Acta Agrophysica, 9(2), 431-442. https://doi.org/10.1016/j.foodres.2011.07.017

Mościcki L., Mitrus M., Wójtowicz A., Oniszczuk T., Rejak A., Janssen L., 2012. Application of extrusion-cooking for processing of thermoplastic starch (TPS). Food Research International, 47(2), 291-299. https://doi.org/10.1016/j.foodres.2011.07.017

Muszyński S., Kwaśniewska A., Oniszczuk T, Szymanek M., Tomczyk A., Leus A., and Gladyszewska B., 2017. Aging of biodegradable thermoplastic starch film under UV-irradiation (in Polish). Przemysł Chemiczny, 96(4), 891-893. https://doi.org/10.15199/62.2017.4.32

Muszyński S., Świetlicki M., Oniszczuk T., Kwaśniewska A, Świetlicka I, Arczewska M., Oniszczuk A., Bartnik G., Kornarzyński K., and Gladyszewska B., 2016. Effect of the surface structure of thermoplastic starch pellets on the kinetics of water vapor adsorption (in Polish). Przemysł Chemiczny, 95(4), 865-869.

Nabar Y., Narayan R., Schindler M., 2006. Twin-screw extrusion production and characterization of starch foam products for use in cushioning and insulation applications. Polymer Eng. Sci., 46(4), 438-451. https://doi.org/10.1002/ pen. 20292

Oniszczuk T., Mitrus M., Wójtowicz A., and Mościcki L., 2015. Addition of bark in the production of the starch-based composites (in Polish). Przemysł Chemiczny, 94(10), 1748-1751.

Oniszczuk T., Pilawka R., and Oniszczuk A., 2013. Effect of powdered pine bark on thermal resistance of thermoplastic starch (in Polish). Przemysł Chemiczny, 8, 1554-1557.

Oniszczuk T. and Pilawka R., 2013. Effect of cellulose fibers on thermal strength of thermoplastic starch (in Polish). Przemysł Chemiczny, 92(2), 265-269.

Pushpadass H.A., Babu G.S., Weber R.W., Hanna M.A., 2008. Extrusion of starch-based loose-fill packaging foams: effect of temperature, moisture and talc on physical properties. Packaging Technol. Sci., 21, 171-183. https://doi.org/10.1002/pts.809

Rejak A., Wójtowicz A., and Oniszczuk T., 2013. Some properties of starchy films with poly(vinyl alcohol) and linen oil addition (in Polish). Przemysł Chemiczny, 92(11), 2022-2026.
Stasiak M., Molenda M., Bańda M., Wiącek J., Parafiniuk P., and Gondek E., 2017. Mechanical and combustion properties of sawdust-Straw pellets blended in different proportions. Fuel Proc. Technol., 156, 366-375. https://doi.org/10.1016/j.fuproc.2016.09.021

Stasiak M., Molenda M., Opaliński I., and Błaszczak W., 2013. Mechanical properties of native corn, wheat and potato starches. Czech J. Food Sci., 31(4), 347-354. https://doi.org/10.17221/348/2012-cjfs

Szyszlak-Barglowicz J., Slowik T., Zajac G., and Piekarski W., 2013. Inline plantation of Virginia mallow (Sida hermaphrodita R.) as biological acoustic screen. Rocznik Ochrona Środowiska, 15, 524-537.

Teixeira E., Dá Róz A., Carvalho A., and Curvelo A., 2007. The effect of glycerol/sugar/water and sugar/water mixtures on the plasticization of thermoplastic cassava starch. Carbohydrate Polymer, 69, 619-624. https://doi.org/10.1016/j.carbpol.2007.01.022

Thomas D. and Atwell W., 1999. Starches, Eagan Press.

Wang L., Ganjyal G., Jones D., Weller C., and Hanna M., 2005. Modeling of bubble growth dynamics and nonisothermal expansion in starch-based foams during extrusion. Advances in Polymer Technol., 24(1), 29-45. https://doi.org/10.1002/adv.20030

Willett J.L. and Shogren R.L., 2002. Processing and properties of extruded starch/polymer foams. Polymer, 43(22), 59355947. https://doi.org/10.1016/s0032-3861(02)00497-4

Wójtowicz A., Mitrus M., Oniszczuk T., Mościcki L., Kręcisz M., Oniszczuk A., 2015. Selected physical properties, texture and sensory characteristics of extruded breakfast cereals based on wholegrain wheat flour. Agriculture and Agricultural Science Procedia, 7, 301-308.

https://doi.org/10.1016/j.aaspro.2015.12.051

Zhang J.-F. and Sun X., 2007. Biodegradable foams of poly(lactic acid)/starch. I. Extrusion condition and cellular size distribution. J. Appl. Polymer Sci., 106(2), 857-862. https://doi.org/10.1002/app.26715

Zhang M.Q., Rong M.Z., and Lu X., 2005. Fully biodegradable natural fiber composites from renewable resources: Allplant fiber composites. Composites Sci. Technol., 65, 2514-2525. https://doi.org/10.1016/j.compscitech.2005.06.018

Zou W., Yu L., Liu X., and Chen L., 2012. Effects of amylose/ amylopectin ratio on starch-based superabsorbent polymers. Carbohydrate Polymers, 87, 1583-1588. https://doi.org/10.1016/j.carbpol.2011.09.060 